\title{
Estimating the Thermal Bridge at Wall Corners with Artificial Neural Network
}

\author{
M. Orosz, J.E. Csanaky \\ Budapest University of Techncology and Economics, \\ Department of Construction Materials and Technologies \\ Müegyetem rkp. 3, H-1111 Budapest, Hungary \\ Phone: +36 14631539 \\ e-mail: orosz.mate@epito.bme.hu
}

\begin{abstract}
Nowadays there are several software products to simulate the heat transfer at thermal bridges. These sophisticated tools are mostly based on Finite Difference or Finite Element Methods. However, there is a demand from energy modelers to estimate the linear thermal transmittance and the lowest internal surface temperature from existing data, instead of employing timeconsuming simulations for each case. This paper investigates wall corners with and without thermal insulation by using Artificial Neural Network (ANN), as a Soft Computing technique. It gives simple formulas that estimate the thermal bridge at wall corners with an acceptable level of accuracy.
\end{abstract}

Keywords: thermal bridge, linear thermal transmittance, artificial neural network, radial basis function

\section{Introduction}

Thermal bridges have a significant effect on energy performance and comfort of buildings, therefore their investigation during the design phase is inevitable. In case of high performance buildings thermal bridges' relative contribution to transmission heat loss is even greater [17]. Moreover, moisture condensation at thermal bridges is one of the mean reasons for physical degradation of building constructions [18].

The variables describing this phenomenon are the linear thermal transmittance $(\Psi)$ $[\mathrm{W} / \mathrm{mK}]$, measuring heat loss, and the lowest internal surface temperature $(\Theta)$, indicating possible moisture condensation. To calculate these values, different building energy software products are available, e.g. Therm 7, Heat 3, heat transfer module of Comsol Multiphysics etc. $[1,14,15]$. These mostly apply numerical methods (Finite Difference Method (FDM) or Finite Elements Method (FEM)) to approximate the heat transfer through the building envelope. However, in practice, simpler and less expensive estimations are needed. There are spreadsheets available for many previously investigated cases [5], but the numerous possible building materials and design options demand a new approach. 
A thermal bridge can be described by a multivariable function, where independent variables are the physical and geometrical properties of building elements, such as thickness and thermal conductivity; and dependent variables are the linear thermal transmittance $(\Psi)$ and the lowest (dimensionless) temperature of the internal surface $(\Theta)$ $[4,6]$.

Numerical simulations are carried out for many cases [5], and similar cases can be interpolated from these results. However; in this paper, instead of interpolating from existing data, functions describing the phenomenon are approximated. The most common applicable techniques to estimate an unknown function are polynomial and rational function approximations, both having advantages and disadvantages. Polynomial models have a simple form, and with sufficiently high degree of its term, it approximates the target function accurately. However, it has poor generalization capability (overlearning, Runge phenomena) [19]. Rational function approximation has better generalization properties, however it is less known by engineers.

Recently, Soft Computing techniques have also been used for modelling input-output relations. This field of computer science, which emerged in the early 1990s, includes several sub-fields such as Probabilistic Models, Fuzzy Systems, Evolutionary Algorithms and Artificial Neural Networks (ANN). According to the universal approximation theorem, a multilayer feed-forward neural network is deemed a universal approximator $[3,12,20]$, since it has the ability to approximate any continuous function with arbitrary precision. In this paper a neural network model is developed by using the Neural Network application of Wolfram Mathematica [16].

\section{Methodolgy}

In this research Radial Basis Function (RBF) Network is applied to approximate the unknown function [2], since it is the most promising neural network model for data approximation [11]. Fig. 1. shows an RBF Network with inputs $x_{1}, \ldots, x_{k}$ and output $\hat{y}$.

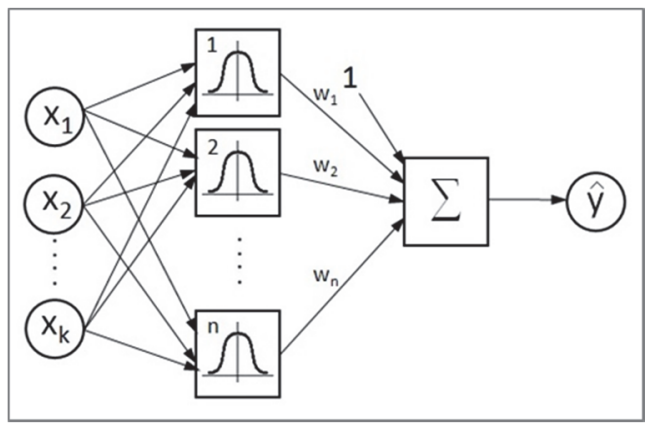

Figure 1. RBF network with one output

The arrows in the figure represent the information-flow in the network. It consists of one hidden layer, where the basis functions are usually Gaussian bell shaped curves (1) with two parameters $(\lambda \mathrm{i}, \beta \mathrm{i})$ :

$$
e^{-\lambda^{2}(x-\beta)^{2}}
$$


The output is formally expressed in equation (2):

$$
\hat{y}(\theta)=g(\theta, x)=\sum_{i=1}^{\mathrm{n}} w_{i} e^{-\lambda_{i}^{2}\left(x-\beta_{i}\right)^{2}}+w_{\mathrm{n}+1}+\chi_{1} x_{1}+\ldots+\chi_{k} x_{k}
$$

where $\mathrm{n}$ is the number of neurons, each neuron contains an RBF type activation function. The parameters (wi, $\beta \mathrm{i}, \lambda \mathrm{i}$ ) are tuned so that the training data fit the network output in least square sense [10]. The RBF network usually contains a linear part as well, its parameters are $\chi_{1}, \ldots, \chi_{\mathrm{k}}$. The output is formed by the weighted sum of the neuron outputs, the bias $\left(\mathrm{w}_{\mathrm{n}+1}\right)$ and the optional linear part. An RBF network can be multi-output as well, as our research demonstrates it.

\section{Data Preparation}

In this paper two types of wall corners are investigated (see Fig. 2.). The first one is not insulated; the other one contains continuous, external thermal insulation. The thermal transfer was simulated previously with ANSYS 11 and HEAT3 Version 5.0. [5]. The data sets for neural networks are composed from these simulation results.

The first data set consists of 106 vectors, each containing 4 elements: width of wall $\left(\mathrm{M}_{\text {wall }}=20,25,28,30,40,50,60,65,70,75 \mathrm{~cm}\right)$, thermal conductivity $\left(\lambda_{\text {wall }}=0.05-\right.$ $0.90 \mathrm{~W} / \mathrm{mK})$ as input; linear thermal transmittance $(\Psi=0.015-0.307 \mathrm{~W} / \mathrm{mK})$, and the lowest internal surface temperature in case of $1^{\circ} \mathrm{C}$ air temperature difference $(\Theta=0.460$ $-0.941)$ as output.

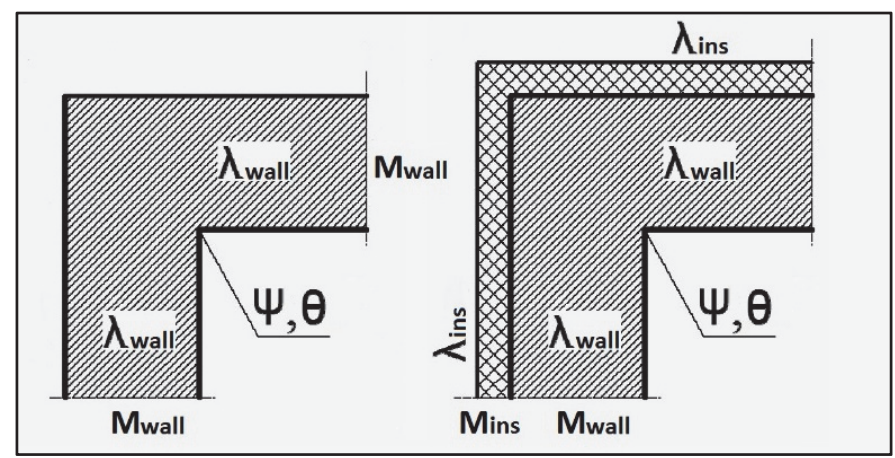

Figure 2. Investigated wall corners (non-insulated and with continuous thermal insulation)

A neural network requires a training set, which, in the first case, contains two-thirds of all the vectors. This training set fulfils certain requirements, i.e. every point being at the boundary is in the training set in order to avoid inaccuracy caused by extrapolation; and the training points are evenly distributed as well. In order to check the accuracy of the network, a validation set is also established containing the rest of the points (see Fig. 3.). 

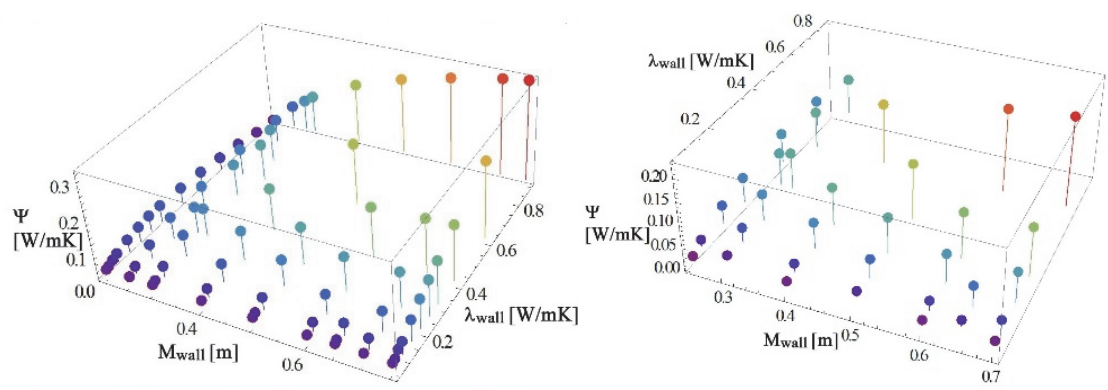

Figure 3. Training set (left) and the validation set (right) for the linear thermal transmittance ( $\Psi)$ at non-insulated wall corners

In the second case, when the wall corner is insulated, there are more possible combination of physical properties. Therefore, more simulation data (340) are used, each representing a possible combination of thickness and thermal conductivity of the wall as well as the thermal insulation. These data compose the input $\left(\mathrm{M}_{\text {wall }}=20,40,60,80 \mathrm{~cm}\right.$; $\left.\lambda_{\text {wall }}=0.1-3 \mathrm{~W} / \mathrm{mK}, \mathrm{M}_{\text {ins }}=0,5,10,20,40 \mathrm{~cm}, \lambda_{\text {ins }}=0.02-0.10 \mathrm{~W} / \mathrm{mK}\right)$. The output has two components: the linear thermal transmittance $(\Psi=0.025-4.360 \mathrm{~W} / \mathrm{mK})$, and the lowest internal surface temperature in case of $1^{\circ} \mathrm{C}$ air temperature difference $(\Theta=$ $0.430-0.990)$. In this model there is no validation set, all the data are used for training in order to reach the most accurate result. (The ultimate goal is to utilize the analytical form of the result to create a simple calculator tool for engineers.)

The input data are normalized into $[0,1]$ interval in both cases in order to increase the sensitivity of the network; i.e. a larger gradient section of the activation function is used during teaching the neural network.

\section{Results}

In case of the non-insulated corner, 4 active neurons are used during the initialization of the network (see Fig. 4.). The training time is set to maximum 500 iterations, it stops at 66 iterations (see Fig. 5.).

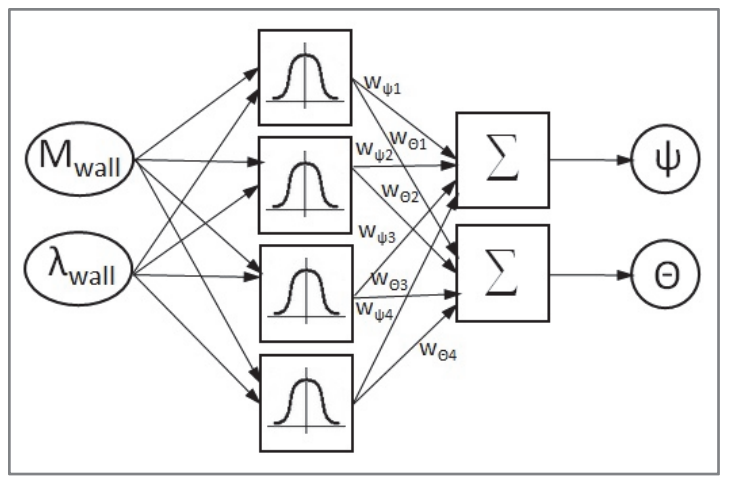

Figure 4. Neural network model - Non-insulated wall corner ( $n=4$ active neurons) 


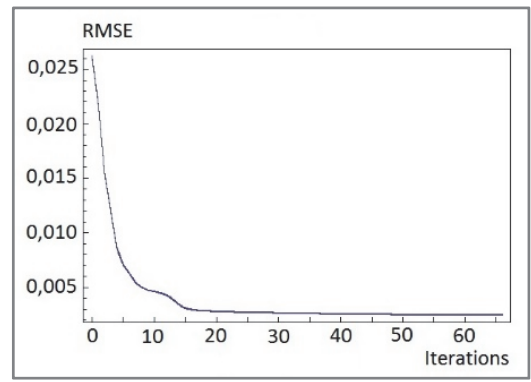

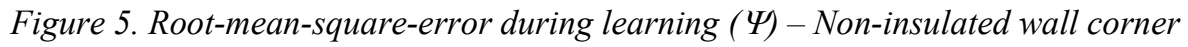

After the learning process, the output i.e. the linear thermal transmittance $(\Psi)$ and the internal surface temperature $(\Theta)$ can be expressed in analytical form by equations $(3)$ and (4):

$$
\begin{gathered}
\psi_{\text {wall }}=A_{\psi}-\sum_{i=1}^{4} w_{\psi_{i}} e^{-\alpha_{i}\left(c_{i}+C\left(-M_{\text {wall.min }}+M_{\text {wall }}\right)\right)^{2}-\alpha_{i}\left(d_{i}+D\left(-\lambda_{\text {wall.min }}+\lambda_{\text {wall }}\right)\right)^{2}}+ \\
+\chi_{\psi 1}\left(-M_{\text {wall.min }}+M_{\text {wall }}\right)+\chi_{\psi 2}\left(-\lambda_{\text {wall.min }}+\lambda_{\text {wall }}\right) \\
\Theta_{\text {wall }}=A_{\theta}+\sum_{i=1}^{4} w_{\theta_{i}} e^{-\alpha_{i}\left(c_{i}+C\left(-M_{\text {wall.min }}+M_{\text {wall }}\right)\right)^{2}-\alpha_{i}\left(d_{i}+D\left(-\lambda_{\text {wall.min }}+\lambda_{\text {wall }}\right)\right)^{2}}+ \\
+\chi_{\theta 1}\left(-M_{\text {wall.min }}+M_{\text {wall }}\right)+\chi_{\theta 2}\left(-\lambda_{\text {wall.min }}+\lambda_{\text {wall }}\right)
\end{gathered}
$$

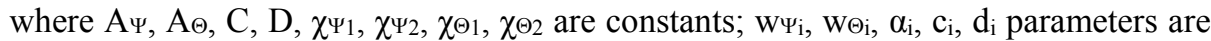
tuned so that the training data fit the network output in least square sense. The root-meansquare-error (RMSE) is less than 0.005 (see Fig. 5). The constant and variable parameters are summarized in Table 1. and Table 2.

Table 1. Constant parameters in case of $n=4$ active neurons - Non-insulated wall corner

\begin{tabular}{|c|c|c|c|c|c|c|c|}
\hline $\mathbf{A}_{\Psi}$ & $\mathbf{A}_{\Theta}$ & $\mathbf{C}$ & $\mathbf{D}$ & $\chi_{\Psi 1}$ & $\chi_{\Psi \mathbf{2}}$ & $\chi_{\Theta 1}$ & $\chi_{\Theta 2}$ \\
\hline-3.31449 & +7.39351 & +1.81818 & +1.17647 & -3.97787 & +0.554254 & +7.37195 & -1.52399 \\
\hline
\end{tabular}

Table 2. Variable parameters in case of $n=4$ active neurons - Non-insulated wall corner

\begin{tabular}{|c|c|c|c|c|c|}
\hline Neuron & $\mathbf{W}_{\Psi_{\mathbf{i}}}$ & $\mathbf{w}_{\Theta \mathbf{i}}$ & $\boldsymbol{\alpha}_{\mathbf{i}}$ & $\mathbf{c}_{\mathbf{i}}$ & $\mathbf{d}_{\mathbf{i}}$ \\
\hline $\mathbf{1 .}$ & -2.99089 & +0.632 & -1.58735 & +1.27706 & -1.04001 \\
\hline $\mathbf{2 .}$ & +253.188 & -476.098 & -0.335266 & -1.61557 & -1.03893 \\
\hline $\mathbf{3 .}$ & -994.824 & +1900.52 & -0.30733 & -1.65803 & -0.961438 \\
\hline $\mathbf{4 .}$ & +749.15 & -1438 & -0.296573 & -1.67726 & -0.930631 \\
\hline
\end{tabular}


Plotting the graph of the functions, $\Psi_{\text {wall }}$ and $\Theta_{\text {wall }}$ surfaces perfectly fit the training points (see Fig 6.). As for the validation set, a slightly worse, but still remarkable coincidence can be seen (see Fig 7.). Notice, that the extrapolation capability of the model is weak, thus the applicable domain of new points should be within the convex hull of input points.
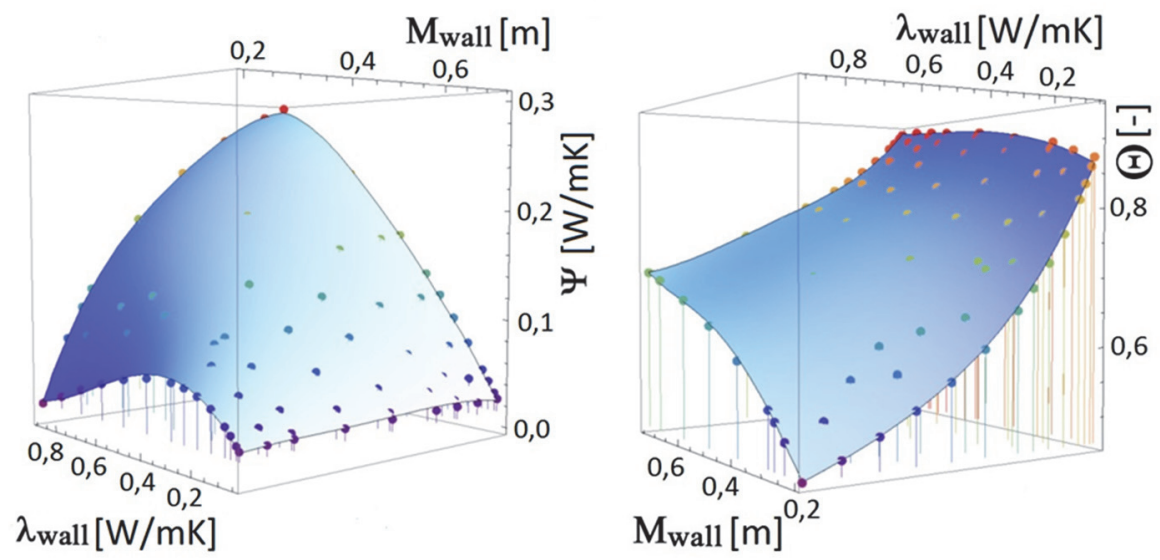

Figure 6. RBF network models of $\Psi$ (left) and $\Theta$ (right), and the training points
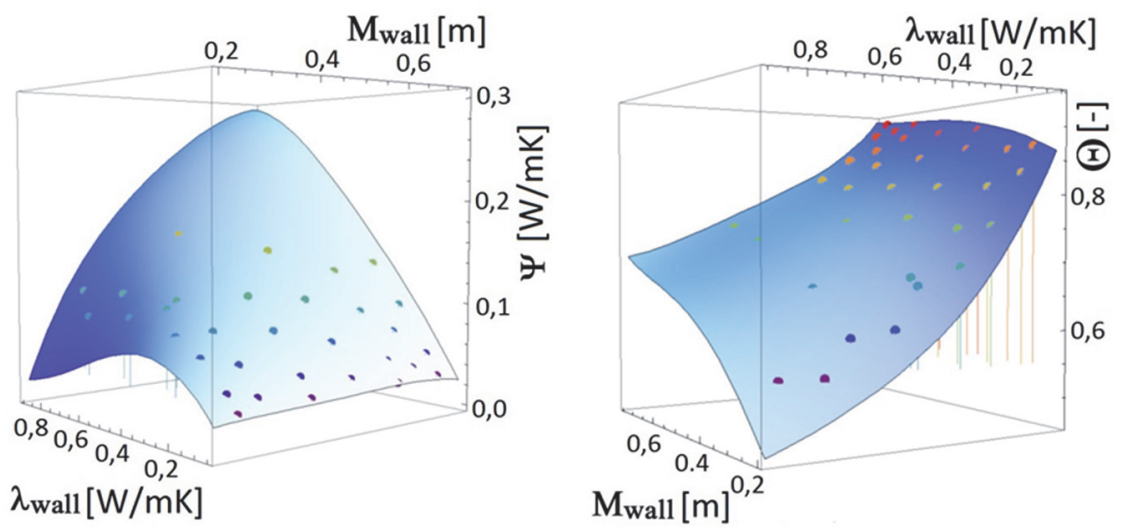

Figure 7. RBF network models of $\Psi$ (left) and $\Theta$ (right), and the validation points

The maximum deviation of the thermal transmittance and the lowest internal surface temperature from simulated data are summarized in Table 3. Since the MSZ EN ISO 14683:2008 standard [13] provides data for simple cases of thermal bridges with a precision of 0.01 , the accuracy of results for the training set is acceptable; however, for the validation set the approximation would require higher accuracy. This can be reached by applying more active neurons or having more points in the training set. 
Table 3. Maximum deviation from simulated data - Non-insulated wall corner

\begin{tabular}{|c|c|c|}
\hline DATA SET & $\begin{array}{c}\text { Linear thermal } \\
\text { transmittance }(\Psi)[\mathbf{W} / \mathbf{m K}]\end{array}$ & $\begin{array}{c}\text { Lowest internal surface } \\
\text { temperature }(\Theta)[-]\end{array}$ \\
\hline Training set & $0.0056(6.55 \%)$ & $0.0082(0.94 \%)$ \\
\hline Validation set & $0.0565(64.72 \%)$ & $0.0695(12.68 \%)$ \\
\hline
\end{tabular}

In case of the insulated wall corner, the initialization of the longer data vector and more input data demand more neurons: a hidden layer with 40 neurons gives optimal accuracy (see Fig. 8.).

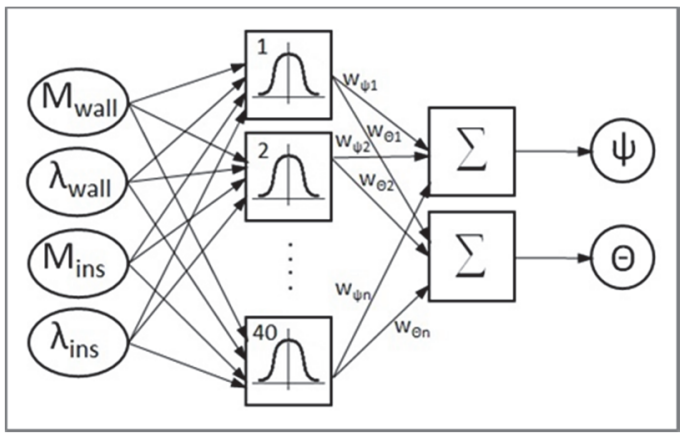

Figure 8. Neural network model - Insulated wall corner ( $n=40$ active neurons)

After the training process, which is also longer with 600 iterations, the root-meansquare-error (RMSE) is less than 0.01. The results, the linear thermal transmittance and the internal surface temperature can be expressed in analytical form by equations (5) and (6):

$$
\begin{aligned}
& \psi_{\text {wall }}= \\
& =A_{\psi} \\
& +\sum_{i=1}^{40} w_{\psi_{i}} e^{-\alpha_{i}\left(c_{i}+\mathrm{C}\left(-M_{\text {wall.min }}+M_{\text {wall }}\right)\right)^{2}-\alpha_{i}\left(d_{i}+\frac{M_{\text {ins }}}{M_{\text {ins.max }}}\right)^{2}-\alpha_{i}\left(f_{i}+F\left(-\lambda_{\text {wall.min }}+\lambda_{\text {wall }}\right)\right)^{2}-\alpha_{i}\left(g_{i}+\frac{\lambda_{\text {ins }}}{\lambda_{\text {ins.max }}}\right)^{2}} \\
& +\chi_{\psi 1}\left(-M_{\text {wall.min }}+M_{\text {wall }}\right)+\chi_{\psi 2} \frac{M_{\text {ins }}}{M_{\text {ins.max }}}+\chi_{\psi 3}\left(-\lambda_{\text {wall.min }}+\lambda_{\text {wall }}\right)+\chi_{\psi 4} \frac{\lambda_{\text {ins }}}{\lambda_{\text {ins.max }}}
\end{aligned}
$$

$\Theta_{\text {wall }}=$

$=A_{\Theta}$

$+\sum_{i=1}^{40} w_{\Theta_{i}} e^{-\beta_{i}\left(c_{i}+\mathrm{C}\left(-M_{\text {wall.min }}+M_{\text {wall }}\right)\right)^{2}-\beta_{i}\left(h_{i}+\frac{M_{\text {ins }}}{M_{\text {ins.max }}}\right)^{2}-\beta_{i}\left(j_{i}+F\left(-\lambda_{\text {wall.min }}+\lambda_{\text {wall }}\right)\right)^{2}-\beta_{i}\left(k_{i}+\frac{\lambda_{\text {ins }}}{\lambda_{\text {ins.max }}}\right)^{2}}$

$+\chi_{\Theta 1}\left(-M_{\text {wall.min }}+M_{\text {wall }}\right)+\chi_{\Theta 2} \frac{M_{\text {ins }}}{M_{\text {ins.max }}}+\chi_{\Theta 3}\left(-\lambda_{\text {wall.min }}+\lambda_{\text {wall }}\right)+\chi_{\Theta 4} \frac{\lambda_{\text {ins }}}{\lambda_{\text {ins.max }}}$ 
each containing 7 constant and 6 variable parameters that are tuned so that the training data fit the network output in least square sense.

The maximum deviations from simulated data are $0.0043[\mathrm{~W} / \mathrm{mK}]$ for the linear thermal transmittance and 0.0051 [-] for the internal surface temperature (Table 4.), demonstrating that this approximation is also accurate enough [13]. However, deviations differ for each training point, and it might result in significant difference at lower values (below 0.01). The deviations are plotted in Fig. 9.

Table 4. Maximum deviation from simulated data - insulated wall corner

\begin{tabular}{|c|c|c|}
\hline DATA SET & $\begin{array}{c}\text { Linear thermal transmittance } \\
(\Psi)[\mathbf{W} / \mathbf{m K}]\end{array}$ & $\begin{array}{c}\text { Lowest internal surface } \\
\text { temperature }(\Theta)[-]\end{array}$ \\
\hline Training set & 0.0043 & 0.0051 \\
\hline
\end{tabular}
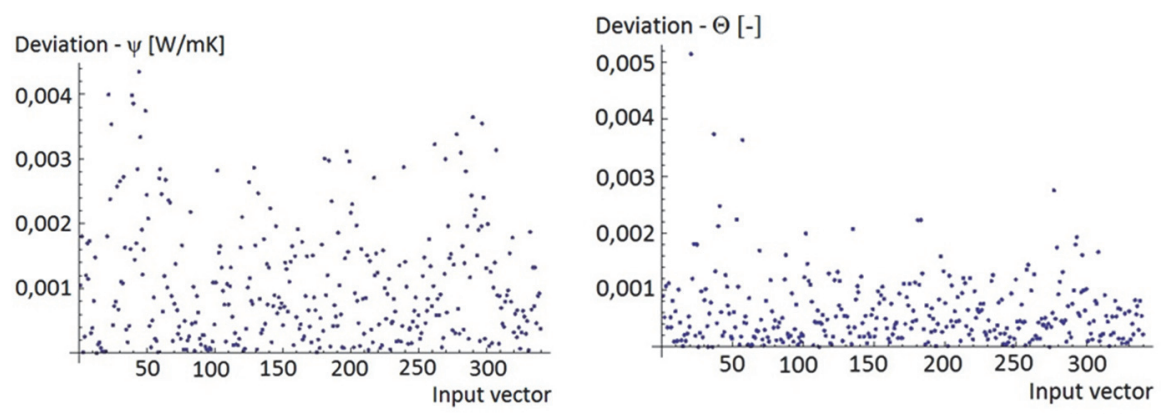

Figure 9. Deviation from simulated data

Insulated wall corner, $\Psi[\mathrm{W} / \mathrm{mK}]$ (left), $\Theta[-]$ (right)

\section{Conclusions}

This paper seeks a new method to approximate the function describing the thermal bridge at wall corners by using Artificial Neural Network modelling. The model uses data of physical properties (thickness, thermal conductivity), and results of previously conducted simulations (linear thermal transmittance - $\Psi$, and the lowest internal surface temperature $-\Theta$ ). Activation functions are radial basis functions (RBF), since it was found the most efficient for this purpose. The paper demonstrates, that in case of a non-insulated wall corner less active neurons (4 active neurons per 106 input data) give an acceptable precision for training data; however, for an insulated wall corner, the more possible combinations of physical properties require more active neurons (40 active neurons per 340 input data). The paper also shows, that the validation set should be chosen thoroughly, since it can have an impact on results: points at the boundary should not be in the 
validation set; and having more points in the validation set i.e. less points in the training set decreases the overall accuracy.

Besides the advantages of this technique, there are some weaknesses as well. Due to the weak extrapolation capability of this method, the physical properties of the investigated thermal bridge must be within the domain of training data. Furthermore, the deviations from the simulated data vary, and it might result in significant difference at lower input values. However, the target function can be approximated with arbitrary precision by increasing the number of active neurons and/or the number of training points.

After the training process the results can be expressed in analytical form that are easily exportable into other software products (e.g. Microsoft Excel) to create a simple calculator for engineers. Further research is suggested, during which input data are considered stochastic variables and the histogram of the output is produced by MonteCarlo simulation.

\section{Acknowledgement}

The authors are grateful to Dr. Béla Paláncz (BME) and Sean McMahon (USGBC) for their valuable feedback and peer review.

\section{References}

[1] Blomberg, T: Heat conduction in two and three dimensions, Computer Modelling of Building Physics Applications. Lund: Dept. of Building Physics, Lund University, Sweden, ISBN 91-88722-05-8, 1996.

[2] Broomhead, DS., Lowe, D,: Multivariable function interpolation and adaptive networks. Complex Systems, Vol. 2, pp 321-355, 1988.

Available at: http://sci2s.ugr.es/keel/pdf/algorithm/articulo/1988-BroomheadCS.pdf, (accessed 31 March 2015), 1988.

[3] Csáji, CsB.: Approximation with Artificial Neural Networks. MSc Thesis, Faculty of Sciences, Eötvös Loránd University, Hungary, 2001.

[4] Csanaky, JE: A legegyszerübb geometriai hőhíd - a derékszögü falsarok. Magyar Építöipar 2009: (3) pp. 107-110, 2009.

[5] Csanaky, JE: Épületszerkezetek energiatudatos fejlesztése az építészeti és épületfizikai tervezés határfelületén. PhD Thesis, Széchenyi István University, Györ, 2012.

[6] Csanaky, JE: Wall-corner - the simplest type of thermal bridges. Acta Technica Jaurinensis, 3: Paper B113, 2010.

[7] EN ISO 10211:2007 Thermal bridges in building construction - Heat flows and surface temperatures - Detailed calculations (ISO 10211:2007). Brussels: CEN, 2007.

[8] EN ISO 10456:2007 Building materials and products - Hygrothermal properties Tabulated design values and procedures for determining declared and design thermal values. Brussels: CEN, 2007.

[9] EN ISO 6946:2007 Building components and building elements - Thermal resistance and thermal transmittance - Calculation method (ISO 6946:2007). Brussels: CEN, 2007. 
[10] Freeman JA: Simulating Neural Networks with Mathematica, Addison Wesley, ISBN: 020156629X, New York, 1994.

[11] Haykin I: Neural Networks: A Comprehensive Foundation, Second Edition, Macmillan, New York, 1999.

[12] Hornik, K, Stinchcombe, M, White, H: Multilayer feedforward networks are universal approximator, Neural Networks, Vol. 2, 1989: (5), pp 359-366, Available at: http://deeplearning.cs.cmu.edu/pdfs/Kornick_et_al.pdf (accessed 31 March 2015), 1989.

DOI: $10.1016 / 0893-6080(89) 90020-8$

[13] MSZ EN ISO 14683:2008 Hőhidak az épületszerkezetekben. Vonal menti hőátbocsátási tényező. Egyszerüsített módszerek és felülírható kiindulóértékek (ISO 14683:2007), 2008.

[14] Nagy, B: Comparative analysis of multi-dimensional heat flow modeling, In: Cosmin G Chiorean (ed.), Proceedings of the Second International Conference for PhD Students in Civil Engineering and Architecture: Full papers. Place and date of conference: Cluj-Napoca, Romania, 10/12/2014-13/12/2014. Cluj-Napoca: Editura UTPress, pp. 468-476, 2014.

DOI: $\underline{10.13140 / 2.1 .2666 .4003}$

[15] Nagy, B: Geometriai modellek kialakításának hatása tetőcsomópontok végeselemes és véges differenciamódszeres többdimenziós hőtechnikai szimulációi esetén. Magyar Építőipar 2014:(5) pp. 202-205, 2014.

[16] Neural Network Documentation, Available at: http://reference.wolfram.com/applications/neuralnetworks/ (accessed 10 February 2013), 2013.

[17] Olsen, L, Radisch, N: Thermal bridges in residential building in Denmark. Brno: KEA energeticka agentura s.r.o, Czech Republic, ISBN 80-902689-6-X, Available at: https://www.tc.cz/files/istec_publications/thermal-bridges.pdf (accessed 8 November 2014), 2002.

[18] Orosz, M: Épületszerkezetek avulása, In: Széll Mária (ed.), Fenntartható energetika az épületszerkezetek tervezésében és oktatásában: Monográfia. 230 p., Budapest: TERC Kereskedelmi és Szolgáltató Kft., 2012. pp. 148-155, ISBN 978963-9968-32-5, 2012.

[19] Paláncz, B, Völgyesi, L: High accuracy data representation via sequence of neural networks. Acta Geodaetica et Geophysica Hungarica Vol. 38, Issue 3, pp. 337-343, Available at: http://sci.fgt.bme.hu/ volgyesi/gravity/neural.pdf (accessed 31 March 2015), 2003. DOI: $10.1556 /$ AGeod.38.2003.3.4

[20] Zainuddin, Z, Pauline, O: Function approximation using artificial neural networks, School of Mathematical Sciences, Universiti Sains Malaysia, 11800 Minden, Penang, Malaysia, Issue 4, Volume 1, 2007, International Journal of Systems Applications, Engineering \& Development 2007:4, Vol 1, Available at: http://ww.naun.org/multimedia/UPress/saed/saed-23.pdf (accessed 8 November 2014), 2007. 